\title{
TRAF6 Gene
}

National Cancer Institute

\section{Source}

National Cancer Institute. TRAF6 Gene. NCI Thesaurus. Code C21469.

This gene plays a role in signal transduction and regulation of apoptosis. It is also involved in the immune response and bone homeostasis. 